\title{
CLINICS IN PLASTIC SURGERY
}

\section{FORTHCOMING ISSUES}

January 2021

Breast Augmentation

Bradley P. Bengtson, Editor

April 2021

Contemporary Approach to Lower Extremity

Reconstruction

Lee L.Q. Pu, Editor

July 2021

Craniofacial Distraction

Roberto L. Flores, Jr., Editor

\section{RECENT ISSUES}

July 2020

Abdominoplasty

Alan Matarasso and James E. Zins, Editors

April 2020

Pain Management in Plastic Surgery

Michael W. Neumeister and Reuben A. Bueno, Editors

January 2020

Fat Grafting to the Face for Rejuvenation, Contouring, or Regenerative Surgery Lee L.Q. Pu, Editor

ISSUE OF RELATED INTEREST

Facial Plastic Surgery Clinics

https://www.facialplastic.theclinics.com/

Otolaryngologic Clinics

https://www.oto.theclinics.com/

THE CLINICS ARE AVAILABLE ONLINE!

Access your subscription at:

www.theclinics.com 